\title{
Author Correction: Genomic and phenotypic analyses of six offspring of a genome- edited hornless bull
}

Amy E. Young (D), Tamer A. Mansour (D), Bret R. McNabb (D), Joseph R. Owen (D), Josephine F. Trott (D), C. Titus Brown (D) and Alison L. Van Eenennaam (D)

Correction to: Nature Biotechnology https://doi.org/10.1038/s41587-019-0266-0, published online 7 October 2019.

In the version of this article initially published online, the color of the red and black squares was reversed in Fig. $4 \mathrm{~d}$ and the labels RCI001 and RCI002 were reversed in Supplementary Tables 1 and 3. The errors have been corrected in the print, PDF and HTML versions of the article.

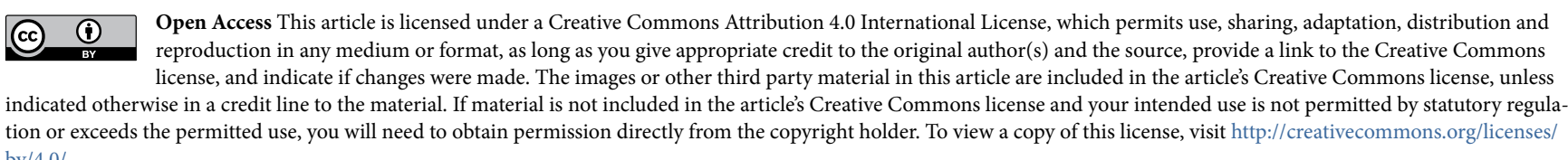
by $/ 4.0 \%$.

Published online: 28 January 2020

https://doi.org/10.1038/s41587-020-0423-5

(c) The Author(s) 2020

\section{Publisher Correction: In situ readout of DNA barcodes and single base edits facilitated by in vitro transcription}

Amjad Askary, Luis Sanchez-Guardado, James M. Linton, Duncan M. Chadly, Mark W. Budde, Long Cai D, Carlos Lois and Michael B. Elowitz (D)

Correction to: Nature Biotechnology https://doi.org/10.1038/s41587-019-0299-4, published online 18 November 2019.

In the version of this article initially published, the $y$-axis label in Fig. $1 \mathrm{~g}$ read "Proportion of cells with active site(s) (\%)." The correct label is "Proportion of cells with no active site(s) (\%)." And, near the bottom of Fig. 4a, the probe for original variant (orange) was shown with a $\mathrm{C}$ nucleotide and the probe for edited base variants (red) was shown with $\mathrm{T}$; these nucleotides were switched with each other. The errors have been corrected in the HTML and PDF versions of the article.

Published online: 27 January 2020

https://doi.org/10.1038/s41587-020-0432-4

(C) The Author(s), under exclusive licence to Springer Nature America, Inc. 2020 